DOI: https://doi.org/10.32839/2304-5809/2021-7-95-19

УДК 821.581-1.09

Трунова О.С.

Київський національний університет імені Тараса Шевченка

\title{
ОСНОВНІ ПОЕТИЧНІ КОНЦЕПЦІЇ У ТВОРЧОСТІ БАЙ ХУА
}

Анотація. Стаття присвячена аналізу основних поетичних концепцій у творчості сучасного китайського поета Бай Хуа, який починає свій творчий шлях у 70-х роках ХХ ст. В цей час активізувалася діяльність прогресивного суспільства, що обумовило піднесення в літературі загалом, і в області поезії, зокрема. Вірші стають художньою цінністю, бо поети повертаються до національних традицій та, в той же час, розглядають і вивчають зразки західної літератури, тож китайська поезія вдихнула в себе нове життя. Політизована поезія маоїстського періоду поступово замінюеться новою, свіжою, вільною, повною роздумів і пошуків, живою поезією. У 80-х роках XX століття в китайській літературі з'являються такі течії, як: література «пошуків коріння», література «шрамів», авангардизм, «туманна поезія», модернізм і постмодернізм тощо. У статті проаналізовано вірші Бай Хуа 1970-1980-х років та визначено вплив літературних течій на поезію першого етапу його творчості.

Ключові слова: Бай Хуа, концепція, течія, поезія, Китай.

Trunova Olena

Taras Shevchenko National University of Kyiv

\section{MAIN POETIC CONCEPTS IN THE WORKS OF BAI HUA}

Summary. The article is devoted to the analysis of the main poetic concepts in the works of the modern Chinese poet Bai Hua, who began his career in the 1970s. At this time the activities of progressive society intensified, which led to the rise in literature in general, and in the field of poetry in particular. Poems become an artistic value, because poets return to national traditions and at the same time consider and study samples of Western literature, so Chinese poetry breathed new life. The politicized poetry of the Maoist period is gradually being replaced by new, fresh, free, full of reflection and search, living poetry. In the 1980s trends such as literature of "roots search", of "scars", avant-garde poetry, "misty poetry", modernism and postmodernism appeared in Chinese literature. The study of stylistic diversity of literature of this period is in scientific interest, because the $80 \mathrm{~s}$ in Chinese literature is a period of a new prose and poetic themes, symbols and images, the beginning of creative freedom. Bai Hua does not refer to any one literary trend, but each of the trends that prevailed in the literature of this period, certainly in one or another way influenced the poetic work of Bai Hua. Poet is a bright representative of modern Chinese literature, author of poems that are full of respect for tradition and, at the same time, reflect the modern life of Chinese society. Bai Hua's poems are full of social and political problems, a number of poems are based on autobiographical moments of his life. In poems he used style of "misty poetry", experimented with the style of "butterflies and tangerines", which is characterized by an ancient literary style, also Bai Hua was part of the group "Seven Men of Sichuan", the poetry organization, which belonged to poets of the third generation. Bai Hua's poems such as: "Autumn Weapon", "Man who guesses by the shape of the clouds", "Book", "Expression" etc. represent his unique personality, therefore, the article provides their translation and analysis. The article analyzed the poems of Bai Hua in the 1970-1980s and determines the influence of literary trends on the poetry of the first stage of his work.

Keywords: Bai Hua, concept, trend, poetry, China.

$\Pi^{\circ}$ остановка проблеми. Бай Хуа починає свою творчість під час нового етапу в китайській літературі, а саме наприкінці 70-х років XX ст. Саме в цей час зароджуеться ненависть інтелігенції до пережитків деспотизму, який проявився в період «культурної револющї». Творча інтелігенція прагнула до руйнування центрального владного дискурсу [1, с. 73]. Саме тому на першому етапі творчості Бай Хуа у його поезіях простежуються революційні настрої та різкі висловлювання. Проаналізувавши вплив тієї чи іншої течії на його творчість, можна краще зрозуміти Бай Хуа і як поета, і як особистість.

Аналіз останніх досліджень і публікацій. Дослідження китайської літератури кінця $\mathrm{XX}$ століття є доволі актуальними. Останні два десятиріччя XX століття в історії Китаю явили безпрецедентний приклад успішного шляху розвитку країни в усіх сорерах [2, с. 240].

Зарубіжні та вітчизняні вчені досліджують особливості кожної з течій џого періоду. «Туманну поезію» вивчають вітчизняні вчені Мурашевич К., Ви- шняк Д., китайські дослідники Мен Лан, Мішел $\mathrm{C}$, Хун Цзичен; дослідженнями модернізму та постмодернізму займаються Желоховцев О., Хузіятова Н., Завідовська К., Урусов В. Такі китайські вчені як Хуан Ібін, Хун Цзичен, Ван Нін займаються впорядкуванням літературних течій і напрямків XX ст.

Виділення невирішених раніше частин загальної проблеми. Поезія Бай Хуа є недослідженою у вітчизняному літературознавстві. В попередніх розвідках ми висвітлювали основні етапи творчості поета, символічність його поезії, часопростір, топоси міста та дитинства тощо. Дана стаття пропонує аналіз поетичних концепцій для більш повного розуміння особливостей творчого поетичного шляху Бай Хуа.

Мета статті. Проаналізувати вплив літературних течій XX століття на становлення Бай Хуа як поета та виділити основні поетичні концепції його творчості.

Виклад основного матеріалу дослідження. Поет Бай Хуа не відносить себе до якоїсь певної течії або літературного напрямку. Він 
Бай Хуа зазначае, що за часів династії Цін в країні панував порядок і справедливість, але в 1840 році все закінчилося, адже після Опіумної війни династія Цін поступилася великими територіями, Китай став напівфеодальною державою, династія почала занепадати. Як ми бачимо, тут автор ретроспективно розглядає минулі історичні події. В наведеному вище поетичному творі можна простежити використання парного стилю2 та традиційної лексики, що одразу надає віршу лаконічності та урочистості водночас.

Бай Хуа пише вірші не заради віршів, а пише для того, щоб відкрити правду та продемонструвати дійсність певного періоду в Китаї [7]. У вірші 《Джонстаун» (“琼斯敦”) поет репрезентуе природу людини на тлі глибоких соціальних проблем: "Осінь змінила весну / Поширюеться нетерпіння та розчарування/ Щасливі дні тяжко пережовуються зубали / В душі хлопиів запаси зброї бажають вибухнути” (“性急与失望四处蔓延 / 示威的牙齿啃着难捱的时日 / 男孩们胸中的军火渴望 爆炸/孤僻的禁忌撕咬着眼泪”)。

В 1980-х роках поезія перестала бути лише літературною формою. В той час будь-яка подія в культурному житті обговорювалася лише в тому випадку, коли вона була відображена в поезії. Будь-які суспільні проблеми, або ж особисті переживання - все це висвітлювали поетичні твори [5, с. 45].

Окрім модерністських настроїв, Бай Хуа ще притаманний стиль "туманної поезіі». Термін “туманна поезія” вперше з'являеться в літературно-критичних працях в 1979-1980-х рр. як реакція на неясність змісту та незвичну новизну образів і форм їх поєднання у віршах молодих поетів [3, с. 125]. Поезію даного періоду характеризуе всесвітній погляд на долю людини, її цікавлять людина і природа як фрілософські категорії, їх співіснування та взаемовплив [2, с. 241]. Разом 3 тим поети наголошують на тому, що не варто забувати свої традиції, національну культуру та заохочують читачів і один одного до її наслідування. У "туманних» віршах Бай Хуа простежуеться багатозначність, «непрозорість», непрямі речення: "Повстає вона $і$ тяжко зневажа / I ompyma 3 ï зyбis kpanae" (“看她正起义, 从肉体 直到喘气 / 直到牙齿浸满盲目的毒汁”) («Ненависть» (“恨”)); “Що ж їй далі робити? / Пливе вона з тишею $i$ з тишею засинає" (“它是什么? 一个种族的形 象/或一个無声的投入的动作”) (“Риба" (“鱼”)); “Кров üого горя тече 3 носу" (“他流下伤心的鼻血”) (《Людина, одягнена в кору берези” (“以桦皮为衣的人”)).

Висновки і перспективи. Проаналізувавши вірші Бай Хуа 70-х-80-х pp. XX ст. можна побачити, що поет не відносить себе до якогось одного літературного напрямку, але кожен з напрямків, які панували в літературі цього періоду, безумовно тим чи іншим чином вплинув на його поетичну творчість. Бай Хуа - поет третього покоління, у творчості якого простежуються ознаки модернізму та «туманної поезії». Ідеологія «туманної поезії» дещо переплітається з ідеологіями імажизму, модернізму, постмодернізму, символізму, авангардизму і т.д. Це пояснюеться тим, що всі ці течії одна за одною почали свое панування в китайській літературі у 80-х роках XX століття, відповідно і творчість Бай Хуа в цей час є доволі експериментаторською та різнобічною.

\section{Список літератури:}

1. Ван Нин. Постмодернистские модификации в современной китайской литературе. Тяньцзиньская общественная наука. 1994. Вып. 1. С. 87-93.

2. Серебряков Е.А., Родионов А.А., Родионова О.П. Справочник по истории литературы Китая. Москва : Восток-Запад, 2005. 336 с.

3. Хайдапова М.Б.О. История формирования и развития «туманной поэзии». Вестник Бурятского государственного университета. 2010. Вып. 8. С. 122-128.

4. Bai Hua. Wind says. The Chinese University of Hong Kong Press. 2012. 208 p.

5. Maghiel van Crevel and Lucas Klein (ed). Chinese Poetry and Translation. Amsterdam: Amsterdam University Press B.V, 2019. 355 p.

6. 柏桦。演春与种梨一柏桦诗文集 ( 1979-2009)。青海人民出版社, 2009。281页。

7. 秋天的武器 - 柏桦的写作. URL: https://www.douban.com/note/704400446/ (дата звернення: 20.07.2021).

\section{References:}

1. Van Nin (1994) Postmodernistskie modifikacii v sovremennoj kitajskoj literature [Postmodern Modifications in Contemporary Chinese Literature]. Tianjin Social Science, vol. 1, pp. 87-93.

2. Serebryakov E.A., Rodionov A.A., Rodionova O.P. (2005) Spravochnik po istorii literatury Kitaya [Reference book on the history of Chinese literature]. Moscow: Vostok-Zapad. (in Russian)

3. Hajdapova M.B.O. (2010) Istoriya formirovaniya i razvitiya "tumannoj poezii" [The history of the formation and development of "misty poetry"]. Bulletin of the Buryat State University, vol. 8, pp. 122-128.

4. Bai Hua (2012) Wind says. The Chinese University of Hong Kong Press.

5. Maghiel van Crevel and Lucas Klein (ed). (2019) Chinese Poetry and Translation. Amsterdam: Amsterdam University Press B.V.

6. 柏桦。演春与种梨一柏桦诗文集 (1979-2009)。青海人民出版社, 2009。281页。

7. 秋天的武器-柏桦的写作. Available at: https://www.douban.com/note/704400446/ (accessed 20 July 2021) 